Russian Academy of Sciences, Far Eastern Branch

Botanical Garden-Institute

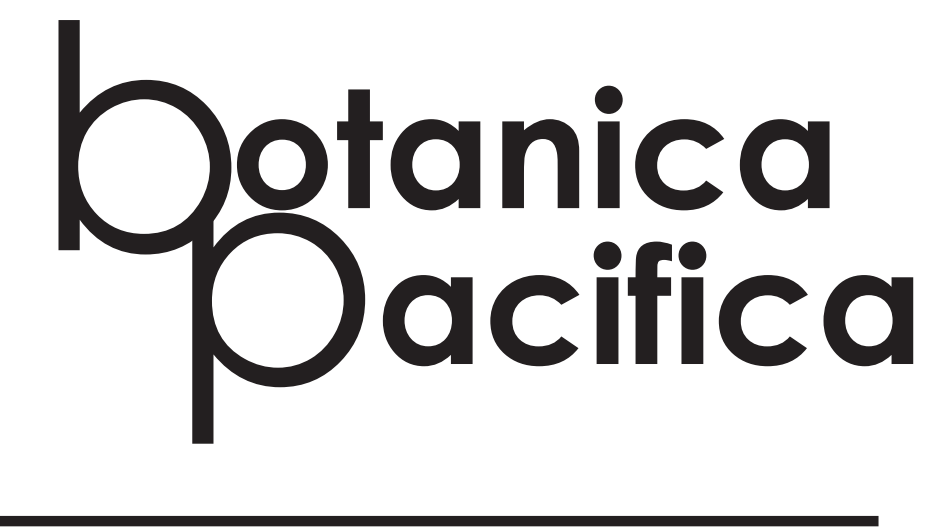

A JOURNAL OF PLANT SCIENCE
AND CONSERVATION

VOLUME 9, NO. 12020 


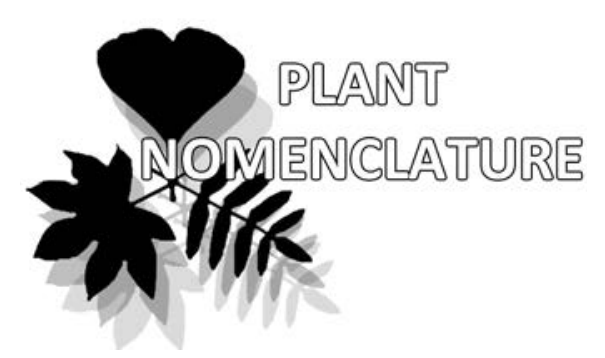

\title{
Lectotypification of the name Salix pseudodepressa (Salicaceae)
}

\author{
Nataliya K. Kovtonyuk ${ }^{1 *}$ \& Irina V. Belyaeva ${ }^{2,3}$
}

Nataliya K. Kovtonyuk ${ }^{1 *}$

e-mail: nkovtonyuk@csbg.nsc.ru

Irina V. Belyaeva ${ }^{2,3}$

e-mail: i.belyaeva@kew.org

${ }^{1}$ Central Siberian Botanical Garden

SB RAS Novosibirsk, Russia

${ }^{2}$ Royal Botanic Gardens, Kew,

Richmond, Surrey, United Kingdom

${ }^{3}$ Institute Botanic Garden UrB RAS

Yekaterinburg, Russia

* corresponding author

Manuscript received: 03.03.2020

Review completed: 06.04.2020

Accepted for publication: 07.04.2020

Published online: 08.04.2020

\begin{abstract}
A B S T R A C T
Problems with typification of the name, Salix pseudodepressa A.K.Skvortsov, are discussed and the lectotypification of this name is made.

Ke y w o r d s : lectotypification, nomenclature, digital herbarium, Caucasus, flora, Salix pseudodepressa, Salicaceae
\end{abstract}

\section{P E 3 Ю M E}

Ковтонюк Н.К., Бемяева И.В. Аектотипификация названия Salix pseudodepressa (Salicaceae). Проблемы типификации названия Salix pseudodepressa A.K.Skvortsov обсуждены и проведена мектотипификация этого названия.

КАючевые слова: кектотипификация, номенклатура, цифровой гербарий, Кавказ, фмора России, Salix pseudodepressa, Salicaceae
During work on the digitization of the herbarium collections of vascular plants at the Central Siberian Botanical Garden SB RAS (Kovtonyuk et al. 2019) and on the World Checklist of Salicaceae sensu stricto (Belyaeva \& Govaerts 2020) the authors of the current paper came across the name, Salix pseudodepressa A.K.Skvortsov, that was published in 1966 (Skvortsov 1966a). The author describing this new species made the type citation: "Typus: Armenia turcica (olim Rossiae prov. Kars), prope opp. Sarykamysch, 29 IV 1914 D.I. Litvinow, in herb. Inst. bot. Leningrad; isotypi in "Herb. Fl. USSR" edentur." In the same year the name was published again (Skvortsov 1966b) and the type was cited on the labels of exiccatae that were distributed to various botanical institutions under the number 4536. However, in the latter case the type citation was corrected to: "Typus: planta nostra; in Herb. Inst. Bot. Acad. Sci. URSS (Leningrad) conservatur. Turcia, prov. Kars, prope opp. Sarykamysch, in palude ad rivulum. Leg. D. Litvinov. 1914 VI 29.”' In his later publications, Skvortsov $(1968,1999)$ used the latter type citation for this species: “Turcia, prov. Kars, prope Sarykamysch, in palude ad rivulum. 29 VI 1914 D.I. Litvinov" (Herb. Fl. URSS N 4536, LE, MW et alibi). Skvortsov's intention to correct the date of collection is supported indirectly by the existing herbarium specimens in LE that show different stages of development of S. pseudodepressa from May to July: LE01044750 (20 V 1902 fragments without developed leaves or catkins); LE01044751 (21 V 1902 fragments without developed leaves but with male catkins); LE01044753 (16 VI 1914 fragments with developed leaves); LE01044752 (7 VII 1910 fragments with developed leaves and catkins with ripened seeds). Comparison of these specimens with the fragments on the exiccatae N 4536
(LE01044748 and LE01044749) makes it clear that the correct month in the type citation in the original publication (Skvortsov 1966a) should be June, not April.

Several exiccatae with the same number 4536 were found: two at LE (LE01044748! and LE01044749!), which were cited by Skvortsov as in the Institute where the type is stored, AAU (D. Litvinov 4536!), C (C10018520!), E (E00235855!) ERE (ERE- general collection 0004891!), L (L1551716!), MHA (MHA0032992!), MW (MW0591818!), NS (NS0002746!), S (S13-14138!), W (W1967-0019592!), US (01269138!). Herbarium codes are given according Triers (2020). As all these exiccatae have the same number, 4536, they belong to the same gathering as is defined in the footnote to Article 8.2 of the ICN and thus are syntypes according to Article 9.6 (Turland et al. 2018), and the lectotype should be chosen. The authors of this paper have already dealt previously with similar cases of typification (Kovtonyuk \& Belyaeva 2015, Stepanova et al. 2019) when no exiccatae was marked as the holotype by the author of the published name. Based on Skvortsov's choice of Institution - LE (first step of typification), one of the specimens, LE01044748, is selected here as the lectotype (second step of typification). The rest of the cited exiccatae under number 4536 from different botanical institutions, which were found using gbif.org portal (GBIF 2020), are isolectotypes.

Salix pseudodepressa A.K.Skvortsov, 1966a, Trudy Bot. Inst. Akad. Nauk Armyansk. S.S.R. 15: 127; 1966b, Spisok rast. Gerb. fl. SSSR 91: N 4536. - S. livida Goerz, 1930, in Grossheim, Fl. Kavk. 2: 8; id. 1934, Feddes Repert. 36: 232. non S. livida Wahlenb. - S. xerophila auct. non Floderus, 1930: Grossheim, 1945, Fl. Kavk. 2 ed. 3: 21. - S. aurita auct. non S. aurita L.: Grossheim, 1945, op. cit. 3: 20. 

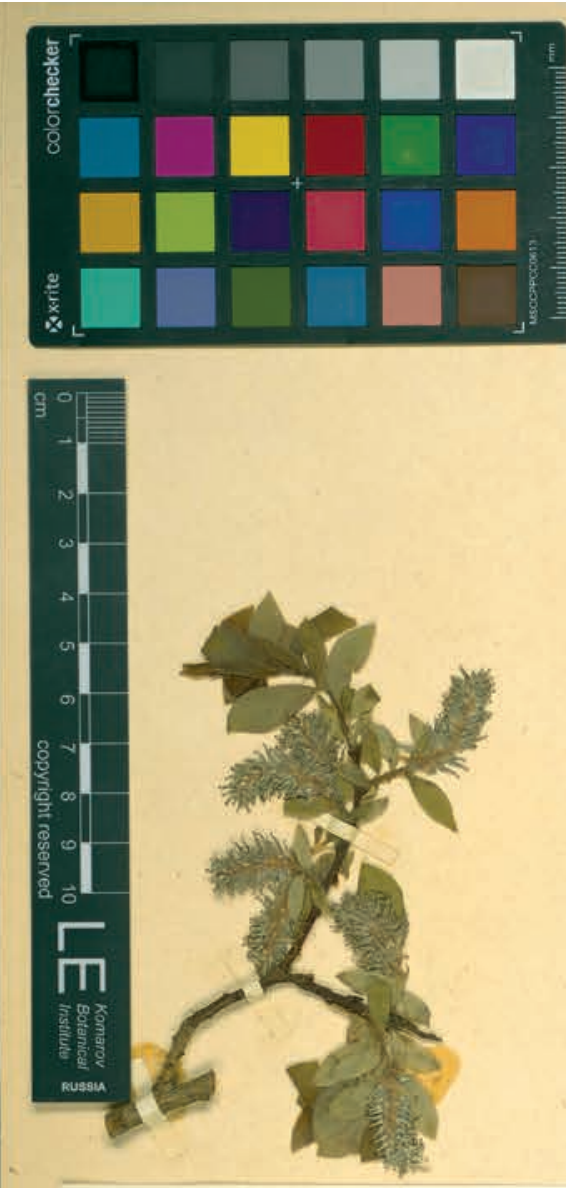

ГEPБAPUЛ ФЛОРЫ ССсP,

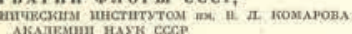

4536. Salix pseudodepressa A. Skvorts. sp, nova

$S$. depressa auct. fl. cauc, plur, non $\mathrm{L}$. $-S$. xerophila auct. non F 1 o d. H a a a p o 1936, Ф3. CCC. 5: 107 , p. p. quoad pl. eauc.; $\Gamma$ p o e c r 1945, Фл. Каak, "132, 2-e, $3: 21$. cibus brevibus sparsis asperso; ramuli annotini autumno $1.2-1.7 \mathrm{~mm}$ inter gemmas ab apice 3-m et 4-m) crass,., olivaceo-brunnescentes, rarius lus minusve rubescentes, laxe boves et $1.8-2.5 \mathrm{~mm}$ th. faeie adaxiali applanatae, apice obtuso applanato et interdum plus minusve recurvato, olivaceo-brunnescentes vel rubicundae; stipulao ambitu asymmetricae, semicordatae, margine dentato, saepissime parvae vel fert reductae; petioli $3-7 \mathrm{~mm} / \mathrm{g}$; lamina foliorum elliptica, obovata vel ablancolata, dentato, rarius erenato vel undulato-cronato, glaborrima vel pilis laxis tenuisaimis plus minusve acoumbentibus utrinque fere aequaliter tecta. Amenta coaetanea (vel subserotina?), $15-30$ mmig., pedunculis in $83=$ $8 \mathrm{~mm}$ ot in o $5-15 \mathrm{~mm} \mathrm{Ig.} 2$-5-foliolatis, sat densa (etiam fominea cum brunneseantes, utrinque pilosae: nectarium 1 , subquadratum, 0.2 $0.4 \mathrm{~mm}$ Ig. f filamenta tibera, glabra vel basi pillis parris obsita, ca. $4 \mathrm{~mm} \mathrm{lg}$.

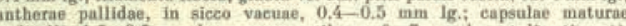
pedicellis $1.5-2.5 \mathrm{~mm}$ Ig., appresse pilosae, $6-7 \mathrm{~m}$. Ty y u us; planta nostra; in Herb. Inst. Bot. Acad. Sel. URSS (Leningrad) conservatur.

A If in It a 8. Species inter $S$. tliensem Rg1, ex Asia Media et $S$. xerophilam Flod. sibiricam quasi medians. A S. zerophila differt gemmis majoribus obtusionibus of praesertim amentis fomineis densis, pedicellis capsularum brevioribs ( $S$. Hiensi - praesertim ramulis tenuioribus, amentis conotis neis, braeteis pallidis, antheris parvis (in $S$, iliensi amenta praecocia, brac-

teae pallidae, antherae $0.6-0.7 \mathrm{~mm}$ lg.).
Habitat in Caecaso (in Armenia, Daghestanta, rarivis in Balkaria) in pinetis, botuletis et fruticetis regionis silvaticae superioris n $\mathrm{n}$ mol

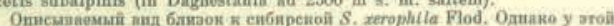

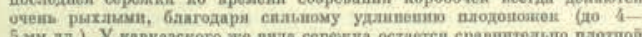

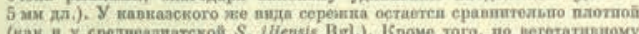

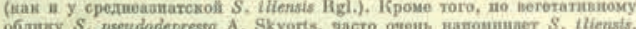

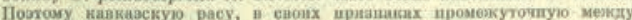

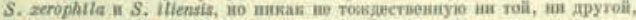

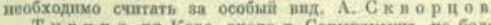

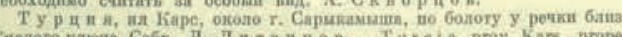

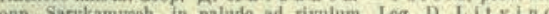
opp. Sarykamy: $1914 \mathrm{VI} 29$.
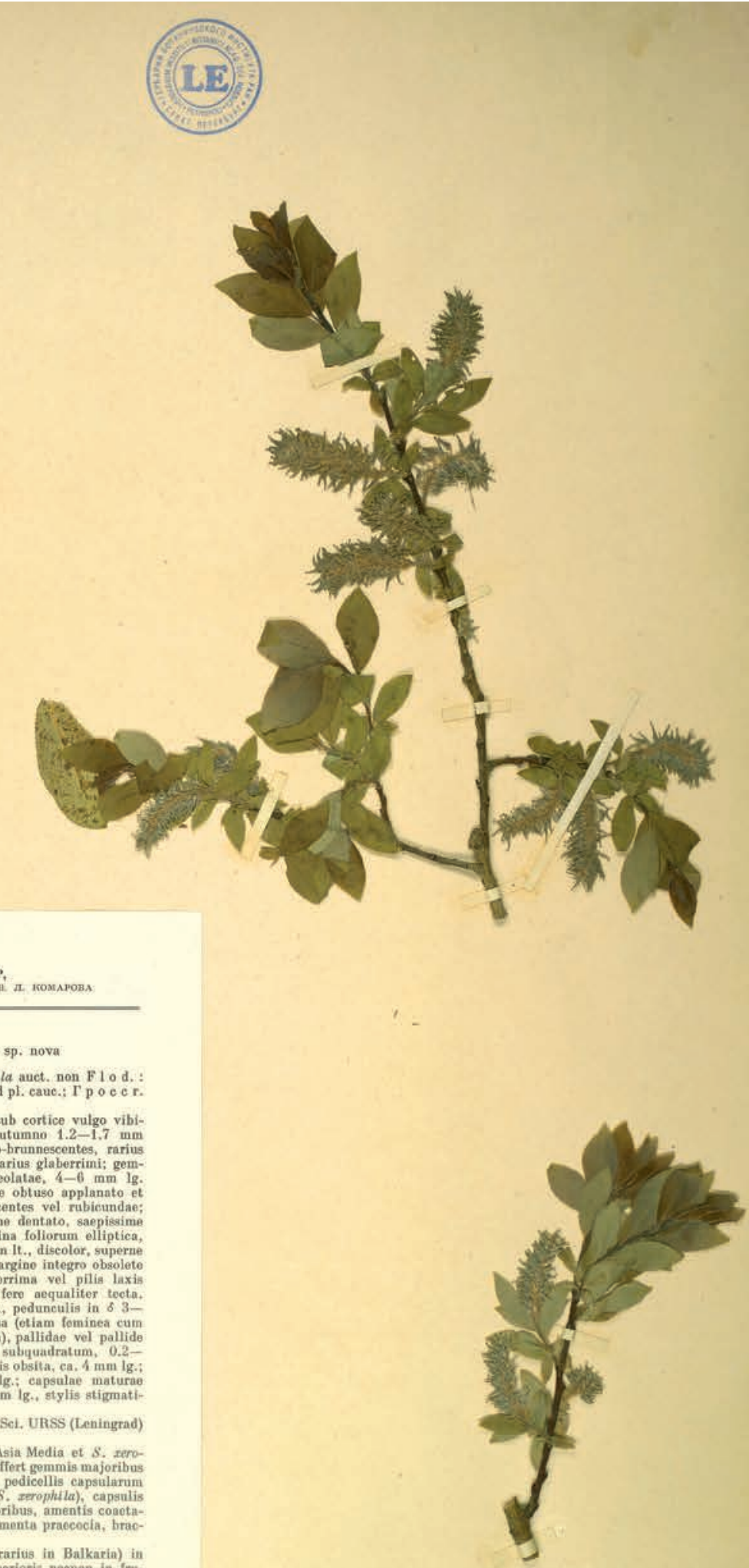

Figure 1 Lectotype of Salix psendodepressa A.K.Skvortsov (LE01044748) 
Lectotype (designated here): ASIA, Turkey, Kars: Armenia turcica, Sarykamysch [40²0'24"N 42³4'12"E], 29 VI 1914 D.I. Litvinov, N 4536 “Herb. Fl. URSS” LE (LE01044748!). Figure 1.

Isolectotypes: AAU (D. Litvinov 4536!), C (C10018520!), E (E00235855!), ERE (ERE-general collection 0004891!), L (L1551716!), MHA (MHA0032992!) MW (MW0591818!), NS (NS0002746!), S (S13-14138!), W (W 1967-0019592!), US (01269138!).

Distribution. According to Skvortsov (1999), the distribution of $S$. pseudodepressa is limited to the Caucasus. This is a rather rare plant. Its area consists of three isolated locations: in Turkish Armenia (5 known places), Dagestan (13 places), and Balkaria (2 places). It grows in pine and birch stands, on rocks, and in damp depressions in the upper forest and subalpine zones at 1,600-2,300 $\mathrm{m}$.

\section{ACKNOWLEDGEMENTS}

The authors appreciate the great help of Vladimir I. Dorofeev and Alexey V. Grebenyuk (LE), Nina Yu. Stepanova (MHA) and the staff of the research group USU - Herbarium CSBG (NS, NSK) for scanning the specimens and creation of the Digital Herbarium CSBG (http://herb. csbg.nsc.ru:8081) and especially Irina Han for providing geolocation for the 'locus classicus'. We also are thankful to Dr. Keith Chamberlain (UK) for linguistic corrections.

\section{LITERATURE CITED}

Belyaeva, I.V. \& R.H.A. Govaerts 2020. Salix L. In: The World checklist of vascular plants (WCVP) (R.H.A. Govaerts, ed.). Available from: https://wcvp.science.kew.org/. Last accessed 02.03.2020.

GBIF 2020. The Global Biodiversity Information Facility. Available from: https://www.gbif.org/occurrence/search? taxon_key=5582042 Last accessed 02.03.2020.

Kovtonyuk, N. \& I. Belyaeva 2015. Nomenclatural and taxonomic notes on the names published by M.G. Popov in Salix L. and Populus L. (Salicaceae). Skevortsovia 2(2): 126-140

Kovtonyuk, N., I. Han \& E. Gatilova 2019. Digital herbarium collections of the Central Siberian Botanical Garden SB RAS, Novosibirsk, Russia. In: Information technologies in the research of biodiversity (I. Bychkov \& V. Voronin, eds), pp. 22-27, Springer Proceedings in Earth and Environmental Sciences. Springer, Cham.

Skvortsov, A.K. 1966a. Review of willows from the Caucasus and Asia Minor. Trudy Botanicheskogo Instituta Akademii Nauk. Armyanskoy SSR 15:91-140 (in Russian). [Скворцов А.К. 1966. Обзор ив Кавказа и Малой Азии // Труды Ботанического института Армянской ССР. T. 15. C. 91-140].

Skvortsov, A.K. 1966b. No 4536. Salix pseudodepressa A.K.Skvortsov. In: Schedae ad Herbarium Florae URSS ab Instituto Botanico Academiae Scientiarum URSS editum. XVI, fasc. 89-94 (№ № 4401-4700) (S.K. Czerepanov, ed.), pp. 70-71, Nauka, Moscow, Leningrad (in Russian). [Скворцов А. K., 1966b. № 4536 Salix psendodepressa A.K.Skvortsov Список растений гербария флоры СССР, издаваемого Ботаническим институтом им. B. А. Комарова Академии наук СССР. Москва; АенинграА, Наука. Т. 16, вып. 91. С. 70-71].

Skvortsov, A.K. 1968. Willows of the USSR. A taxonomic and geographic revision. Nauka, Moscow, 264 pp. (in Russian). [Скворцов А.К. Ивы СССР. Систематический и географический обзор. М.: Наука. 264 с.].

Skvortsov, A.K. 1999. Willows of Russia and adjacent countries. Taxonomical and geographical Revision. University of Joensun Faculty of Mathematics and Natural Sciences Report Series 39:1-307.

Stepanova, N.Y., S.A. Poluektov \& I.V. Belyaeva 2019. Clarification on the typification of Salix sphenophylla A.K. Skvortsov subsp. pseudotorulosa A.K.Skvortsov (Salicaceae). Skvortsovia 5(1):9-13.

Thiers, B. (ed.) 2020. [Continuously updated] Index Herbariorum: A global directory of public herbaria and associated staff. New York Botanical Garden's Virtual Herbarium. Available from: http://sweetgum.nybg.org/science/ih/ Last accessed 01.03.2020.

Turland, N.J., J.H. Wiersema, F.R. Barrie, W. Greuter, D.L. Hawksworth, P.S. Herendeen, S. Knapp, W.-H. Kusber, D.-Z. Li, K. Marhold, T.W. May, J. McNeill, A.M. Monro, J. Prado, M.J. Price \& G.F. Smith (eds) 2018. International Code of Nomenclature for algae, fungi, and plants (Shenzhen Code) adopted by the Nineteenth International Botanical Congress Shenzhen, China, July 2017. Regnum Vegetabile 159. Koeltz Botanical Books, Glashütten, 254 pp. 